Proceedings

\title{
INFLUENCE OF Ta ADDITION ON Tc OF Bi BASE SUPERCONDUCTOR
}

\author{
$\mathrm{Bi}$ 系酸化物超伝導体の $\mathrm{T}_{\mathrm{C}}$ に及ぼす $\mathrm{Ta}$ 添加の影響 \\ Akitsugu Ono, Kaoru Usui, Nobutake Hirai, Yuichi Kawaguchi, Hiroko Yamamoto, \\ Kazuya Oguri and Yoshitake Nishi. \\ Department of Materials Science, Tokai University, 1117 Kitakaname, \\ Hiratsuka, Kanagawa, 259 - 12 Japan. \\ ( Accepted for publication 17 November 1994 )
}

1 目的

$\mathrm{Bi}$ 系酸化物超伝導体は、100 K 以上の高い超伝導 遷移温度（ $\mathrm{T}_{\mathrm{c}}$ ）を示すため超伝導材料の中でも非常 に有望視されており、実用化に向けて数多くの研究が なされている。一方、超伝導特性の向上を目的として 様々な元素を添加する研究が多くの研究者によって行 われている。例えば Ti 添加では添加量を増やしても 高い $\mathrm{T}_{\mathrm{c}}$ を保持することが報告されている。 とから、Ti と同族元素である Ta の添加によっても 状態密度に同様の影響を与え、 $\mathrm{T}_{\mathrm{c}}$ に関して類似の効 果が得られる可能性がある。

そこで本研究では、Bi 系酸化物超伝導体に Ta を 添加し、超伝導遷移温度 $\left(\mathrm{T}_{\mathrm{c}}\right)$ の変化について検討 した。

\section{2 方法}

試料の基本出発組成は、 $\mathrm{Bi}_{1.6} \mathrm{~Pb}_{0 .}{ }_{4} \mathrm{Sr}_{2} \mathrm{Ca}_{2} \mathrm{Cu}_{3-\mathrm{z}} \mathrm{Ta}_{2} \mathrm{O}_{\mathrm{x}}$ $(0<\mathrm{z}<0.4)$ とし、Fig. 1 のフローチャートに 従い固相反応法により作製した。2 Ta 添加は、Cuの 一部を置換する方法で行った。電気抵抗の測定には直 流四端子法を採用し、測定電流密度を $10^{3} \mathrm{~A} / \mathrm{m}^{2}$ とし た。試料の端子間電圧は、Keithley 182 nanovoltmeter ( 分解能 $1 \mathrm{nV}$ ) を用いて測定した。 温度の測定は、Au*0.07\% Fe-クロメル熱電対を用い、 熱起電力の測定には電圧計（DIGITALMULTIMETER） を用い、温度換算した。温度換算は NBS レポートに 基づいて、ヘリウム沸点温度（4.2 K ）、 $\mathrm{Nb}$ の $\mathrm{T}_{\mathrm{c}}$ $(9.3 \mathrm{~K})$ 、窒素沸点温度 $(77.3 \mathrm{~K})$ 、水点温度 ( $273.2 \mathrm{~K}$ ）の 4 つの定点、及び標準白金抵抗温度 計を用いて校正した。なお、温度の制御は熱漏孔法に より行った。
超伝導遷移温度 $T_{c}$ は、Fig. 2 の様に定義した。 $\mathrm{T}_{\mathrm{c}}{ }^{*}$ は電気抵抗率が $\mathrm{R}^{\mathrm{on}}$ の $1 / 10$ となるときの温度とした。 な拉、 $\mathrm{R}^{\mathrm{on}}$ は温度に対する電気抵抗率の曲線の傾きが (1) 式で示される直線と接するときの電気抵抗率で ある。

$$
\mathrm{dR} / \mathrm{dT}=0.004 \times \mathrm{R}^{300 \mathrm{~K}} \quad(1)
$$

Nominal composition :

$\mathrm{Bi}_{1.6} \mathrm{~Pb}_{0.4} \mathrm{Sr}_{2} \mathrm{Ca}_{2} \mathrm{Cu}_{3-\mathrm{z}} \mathrm{Ta}_{\mathrm{z}} \mathrm{O}_{\mathrm{x}}$

$$
(0<\mathrm{z}<0.4)
$$

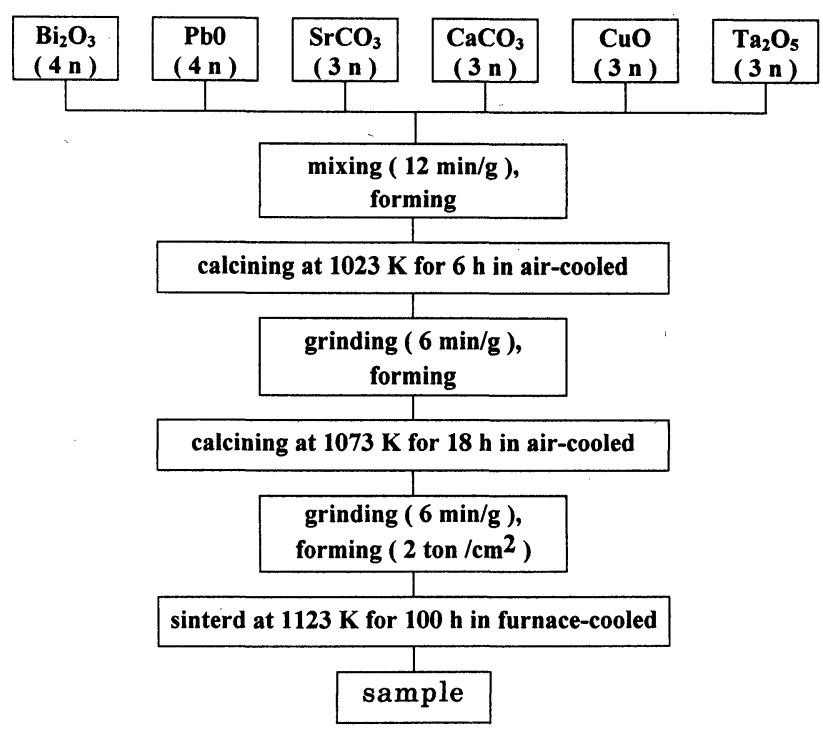

Fig. 1 Sample preparation procedures. 


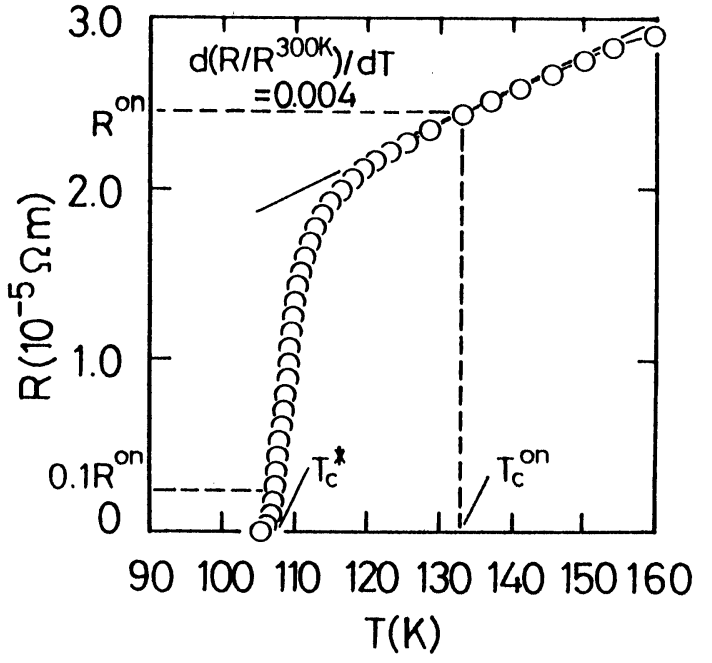

Fig. 2 Change in electrical resistivity $(\mathrm{R})$ with temperature $\left(\mathrm{T}_{\mathrm{c}}{ }^{*}\right)$ for $\mathrm{Bi}_{1.6} \mathrm{~Pb}_{0.4} \mathrm{Sr}_{2} \mathrm{Ca}_{2} \mathrm{Cu}_{3} \mathrm{O}_{\mathrm{x}}$.

\section{3 結果及び考察}

Figure 3 に Ta の添加量 $(\mathrm{z})$ と $\mathrm{T}_{\mathrm{c}}{ }^{*}$ の関係を示 す。この図から、Ta の添加量が $\mathrm{z}=0.15$ の試料まで は $\mathrm{T}_{\mathrm{c}}{ }^{*}$ が $100 \mathrm{~K}$ 以上を保持していることがわかった。

ところで、電子論的考察から $\mathrm{T}_{\mathrm{c}}$ を支配する有力な 因子の一つに、状態密度が考えられる。 ${ }^{3}$ 一般に酸化 物超伝導体では、状態密度が増加すると $\mathrm{T}_{\mathrm{c}}$ が上昇す るということが知られている。状態密度（N）は、電 気抵抗率（R）上り（２）式から求めることができる。

$$
N=A^{\prime} / R^{1 / 2}
$$

また、A'は次の（ 3 ）式より表される。

$$
A^{\prime}=\pi^{2} e^{2} h^{3} L_{0} / 3 m^{*}
$$

ここで、 $A^{\prime}$ は電子の質量 $\left(\mathrm{m}^{*}\right)$ 、電子素量 $(\mathrm{e}) 、$ プランク定数 $(\mathrm{h})$ 及び電子の平均自由行程（ $\left.\mathrm{L}_{0}\right)$ により決定される。な拉、A' は伝導粒子の平均自由行程が 大きく変化しなければ定数と近似できる。このように近似 すると、（2）式から、状態密度は電気抵抗率から推測で きるといえる。従って、電気抵抗率が減少すると状態 密度が増加し $\mathrm{T}_{\mathrm{c}}$ が上昇するが、逆に電気抵抗率が増 加すると状態密度が減少し、 $\mathrm{T}_{\mathrm{c}}$ が低下することがわかる。

Figure 4 に Ta の添加量 $(\mathrm{z})$ と電気抵抗率の関 係を示す。この図から、 $\mathrm{z}=0.15$ 以下の試料では電 気抵抗率の変化が小さく、また $\mathrm{z}=0.2$ 以上の試料 では電気抵抗率が増加する。このことから、 $\mathrm{z}=0.15$ 以下の試料では状態密度がほとんど変化しないために、 $\mathrm{T}_{\mathrm{c}}{ }^{*}$ は $100 \mathrm{~K}$ 以上の高い值を保持したと説明できる。

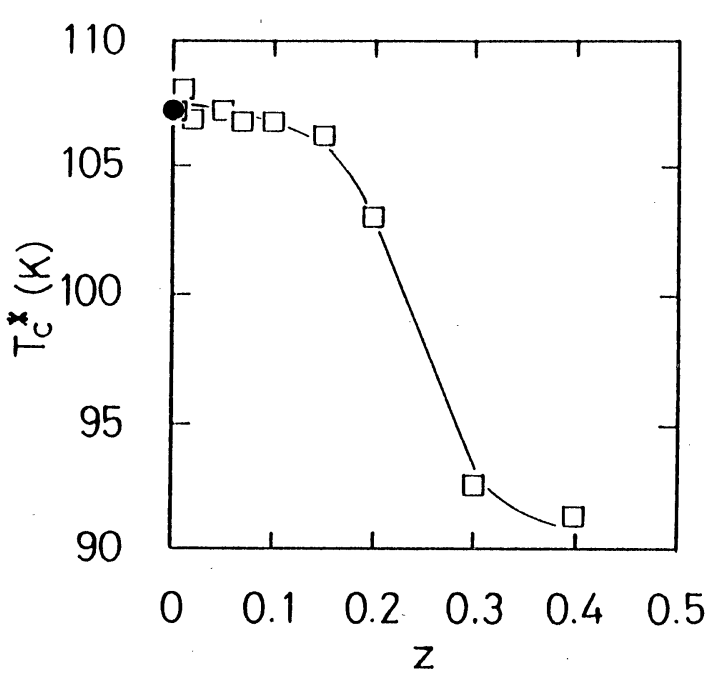

Fig.3 Changes in superconducting transition temperature $\left(\mathrm{T}_{\mathrm{c}}^{*}\right)$ against Ta concentration $(\mathrm{z})$.

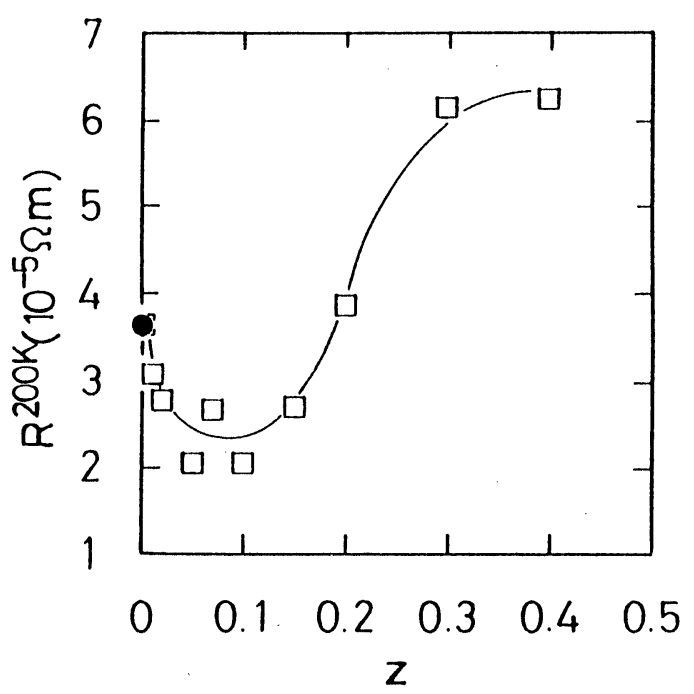

Fig. 4 Changes in electrical resistivity at $200 \mathrm{~K}$ $\left(R^{200 K}\right)$ against Ta concentration $(z)$.

4 結言

$\mathrm{Bi}$ 系酸化物超伝導体に $\mathrm{Ta}$ を添加し、 $\mathrm{T}_{\mathrm{c}}{ }^{*}$ の変化 について調べた結果、 $\mathrm{z}=0.15$ の試料まで $100 \mathrm{~K}$ 以 上の高 $\mathrm{T}_{\mathrm{c}}$ を保持した。

\section{References}

${ }^{1}$ Y. Nishi, K. Nozaki, T. Kurotaki, Y. Kita and K. Oguri, J. Appl. Phys.,71, 350 ( 1992 ).

${ }^{2}$ Y. Nishi, N. Nishinomiya, K. Oguri and S. Tokunaga, J. Appl. Phys. 65, 3927, (1989).

${ }^{3}$ K. Nozaki, S. Ichimura, T. Kurotaki, K. Oguri and Y.Nishi Proc. 4th Inter. Symosium on Superconductivity (1991).

${ }^{4}$ Y. Nishi, K. Oguri, H. Ohinata, K. Tanioka, Y. Kita and N.Nishinomiya, Phy. Rev. B. 41. 6520 ( 1990 ).

'94 SAS Intelligent Symposium 